\title{
Essential oils and Organic Acids: Feed Additive in Broiler Chickens
}

\author{
Raina Doneria ${ }^{1}$, Meenu Dubey ${ }^{1}$, M.K. Gendley ${ }^{1}$, R.C. Ramteke $^{1}$ and Rupal Pathak ${ }^{2 *}$ \\ ${ }^{1}$ Department of Animal Nutrition, ${ }^{2}$ Department of Instructional Livestock Farm Complex, \\ College of Veterinary Science and A.H, \\ Chhattisgarh Kamdhenu Vishwavidyalaya, Durg India -491001 \\ *Corresponding author
}

\section{A B S T R A C T}

The escalating concern over the antibiotic residues in animal and poultry products among the consumers made the hour a prime time to find an

\section{Keywords}

Poultry, Feed additives, Organic acids, Essential oils

\section{Article Info}

Accepted:

26 May 2020

Available Online:

10 June 2020 alternative to antibiotic growth promoters (AGPs) and it have increased a lot over the past decade. New alternatives of antibiotics are essential oils and organic acids. Essential oil usage in animal feeding has been practiced for their role as antibacterial, antiviral, antifungal, antioxidant, digestive stimulant, immune-modulator, hypolipidemic agent and also heat stress alleviator. Organic acids have gained significant attention due to their high nutritional value and antimicrobial benefits. Organic acids and their salts are generally regarded as safe and have been approved by most member states of the EU to be used as feed additives. Thus, the purpose of this paper is to review the potential of using essential oils and organic acids as feed additives in broiler chickens.

\section{Introduction}

The integrity of the gastrointestinal tract (GIT) and the gut microflora play significant roles in nutrition absorption, development of immunity, and disease resistance in broiler chicken. Any alterations in the may have adverse effects on feed efficiency, productivity, and health of chickens. Several feed additives including antibiotic growth promoters (AGPs) are included in poultry feeds to improve the efficiency of production, product quality and to prevent diseases (Brenes and Roura, 2010). The poultry industries are currently transforming towards decreased use of AGPs due to increased concerns regarding development of antibioticresistant bacteria and transfer of residues of AGPs in meat and eggs, which may cause side-effects in humans. In 2006, the European Union (EU) approved a resolution to ban the use of antibiotics as growth promoters for 
animals. Myriad biological products, such as enzymes, probiotics, prebiotics, synbiotics, organic acids and plant extracts(phytobiotics) have been increasingly assessed as substitutes to antibiotic feed additives in diets for monogastric animals (Wenk, 2003).

\section{Essential oils}

Essential oils are natural substances having a protective function against harmful pathogenic microorganisms (Zeng et al., 2015). Essential oils or volatile oils are aromatic oily liquids extracted by distillation from plant parts, such as flowers, buds, seeds, leaves, twigs, bark, wood, fruits and roots. Chemically, essential oils are complex and highly variable mixtures of constituents that belong to two groups: terpenoids (monoterpenes and sesquiterpenes), aromatic compounds (aldehyde, alcohol, phenol, methoxy derivative, and so on) and terpenoids (isoprenoids) (Bakkali et al., 2008; Nazarro et al., 2013).

\section{Biological effects of essential oils}

\section{Antimicrobial activity of essential oils}

The antimicrobial activity of essential oils has been explored in many in vitro assays which showed that thymol, eugenol and carvacrol have high antimicrobial activity against pathogenic bacteria such as Escherichia coli and Salmonella typhimurium, (Bassole and Juliani, 2012; Franz et al., 2010). Thymol, eugenol and carvacrol are structurally similar, and have been proved to exert synergistic or additive antimicrobial effects when combined at lower concentrations (Bassole and Juliani, 2012). In in vivo studies, essential oils used either individually or in combination have shown clear growth inhibition of Clostridium perfringens and $E$. coli in the hindgut and ameliorated intestinal lesions and weight loss than the challenged control birds (Jamroz et al., 2005; Jerzsele et al., 2012).Previously, in a study the antimicrobial properties of 29 essential oils were investigated against 59 microorganisms (Deans and Ritchie, 1987). The antimicrobial property of these essential oil differs with the family it belongs, like Lavandin, Tea tree and Peppermint oils have shown a little or no antimicrobial property but Cinnamon, Oregano, thyme have shown great antimicrobial activity, while Juniper shows an antifungal activity (Dorman and Deans, 2000). The exact anti-microbial mechanism of most of the essential oils is poorly understood. However, it has been suggested that their lipophilic property (Conner, 1993) and chemical structure (Farag et al., 1989) could play a role. It was thus suggested that terpenoids and phenylpropanoids can penetrate the membrane of the bacteria and reach the inner part of the cell because of their lipophilicity, but it has also been proposed that structural properties, such as the presence of the functional groups (Farag et al., 1989), and aromaticityare responsible for the antibacterial activity. It is thought that membrane perforation or binding is the principle mode of action (Shapiro and Guggenheim, 1995; Stiles et al., 1995) leading to an increase of permeability and leakage of vital intracellular constituents , resulting in impairment of bacterial enzyme systems (Farag et al., 1989). The mechanism of antifungal action of cinnamaldehyde has been investigated and it was proposed that it takes place through the reaction with sulfhydryl groups, which are indispensable for the fungal growth, and that the formation of charge transfer complexes with electron donors in the fungus cell could lead to inhibition of cell division and thus interferes with cell metabolism. It was also reported that cinnamaldehyde inhibits the fungal-cell-wall synthesizing enzymes (Bang et al., 2000). It is of note that Gram negative bacteria are more tolerant to the actions of essential oil than Gram-positive bacteria due to their 
hydrophilic constituents in the outer membrane (Giannenas et al., 2013). Coccidiosis, a common parasitosis disease caused by protozoa of the genus Eimeria, leads to malnutrition and performance depression in poultry. The supplementation of essential oils led to a significant reduction of coccidian oocyst excretion and an alleviation of intestinal lesions in chicks (Alp et al., 2012; Bozkurt et al., 2014; Barbour et al., 2015). However, the underlying mechanisms still need to be elucidated.

\section{Effect on digestive processes}

Many studies were conducted concluding that, dietary essential oils addition could improve the digestion process (Mellor, 2000). They enhance the activity of some digestive enzymes like trypsin and amylase (Jang et al., 2007). The pungent compound in essential oils like curcumin, capsaicin and piperine have been found to stimulate the digestive enzyme activities of both intestinal mucosa and also in pancreas (Platel and Srinivasan, 2000). Some studies have reported that the spices or its active components increased the bile salt secretion (Sambaiah and Srinivasan, 1991). Cinnamaldehyde increased the bile secretion in the rat (Harada and Yano, 1975). Lee et al., (2003) reported that cinnamaldehyde in diet had a role in the digestion process while thymol is not involved in these processes. Kreydiyyeh et al., (2000) observed that there was an increase in the absorption of glucose in the intestine of rats when they were fed with anise oil. The hypocholesterolemic effect of lemongrass oil is due to the inhibition of hepatic 3-hydroxy3-methylglutaryl coenzyme A (HMG-CoA) reductase activity which is a key regulatory enzyme in cholesterol synthesis (Elson et al., 1989). In poultry, a 5\% inhibition of HMCCoA reductase activity will lead to lowered serum cholesterol by $2 \%$.

\section{Effect on immune system}

Some essential oils positively influence the avian immune system, since they promote production of immunoglobulins, enhance lymphocytic activity, and boost interferon- $\gamma$ release (Awaad et al., 2010; Faramarzi et al., 2013; Gopi et al., 2014). Supplementing of essential oils in diet positively influenced the activity of the intestinal lymphatic system. Placha et al., (2014) suggested that the supplementation of $0.5 \mathrm{~g}$ of thyme oil per $\mathrm{kg}$ of feed significantly increased $\operatorname{IgA}$ levels. Awaad et al., (2010) revealed that adding eucalyptus and peppermint essential oils to water in the amount of $0.25 \mathrm{ml} \mathrm{L}-1$ results in an enhanced both cell-mediated and humoral immune response. Saleh et al., (2014), who applied thyme and ginger oils observed an improvement in the chicken immunological blood profile through an increased antibody production. Moreover, the oils alleviate the stress caused by vaccination (Barbour et al., 2011; Faramarzi et al., 2013; Gopi et al., 2014). Essential oils promote the production of antibodies, thus enhancing the efficacy of vaccination (Awaad et al., 2010; Faramarzi et al., 2013).

\section{Antioxidant activity}

Chicken body antioxidative stability could be improved by essential oils. Karadas et al., (2014) supplemented diet of chicken with a blend of carvacrol, cinnamaldehyde, and capsicum oleoresin, and found a significant increase in the hepatic concentration of carotenoids and coenzyme Q10 at d 21 of age. Habibi et al., (2014) and Placha et al., (2014) observed that malondialdehyde concentration in liver, duodenal mucosa, and kidney was significantly decreased by supplementing ginger power and thyme oil to broiler diet. Poultry products are particularly prone to oxidative deterioration due to their high concentrations of polyunsaturated fatty acids. 
High efficacy in inhibiting oxidation of fatty emulsions was demonstrated for thyme $(88.0 \%)$, rosemary $(78.8 \%)$, sage $(73.9 \%)$, and lavender $(72.5 \%)$ oils (Amorati et al., 2013). The reviews by Lee et al., (2003) and Khan et al., (2012) showed that thyme oil is effective in retarding oxidant degradation in poultry derived products, such as meat and eggs. The mechanism of action might be the antioxidant activity of the phenolic $\mathrm{OH}$ group which acts as a donor of hydrogen interacting with peroxy radicals during the initial process in lipid oxidation and leading to inhibiting or retarding the hydroxyl peroxide formation (Lee et al., 2003).

\section{Organic acids}

Organic acids are any organic carboxylic acid of the general structure $\mathrm{R}-\mathrm{COOH}$ including fatty acids and amino acids. Not all of these acids have effects on gut microflora. Short chain fatty acids (SCFA) are recognized as potential alternative to antibiotic growth promoter (Paul et al., 2007). Short chain monocarboxylic acids such as citric, propionic, fumeric and formic acids etc. are used in poultry as feed additives.

\section{Biological effects of organic acids}

\section{Antimicrobial activity}

As pathogenic microbes or bacteria multiply in GI tract, they not only damage the villus but also make the intestinal membrane thick due to cell proliferation which causes the infiltration of nutrients tough leading reduced growth performance. The protonated form of organic acids penetrates across bacterial cell wall which then dissociates into its conjugated base form with reduction in cellular $\mathrm{pH}$. Low $\mathrm{pH}$ creates a stressful environment which leads to cellular dysfunction and reduced bacterial multiplication. Recently in a study, it was documented that pathogenic bacterial loads such as coliforms and Clostridia were lesser in Broiler chickens fed diets containing organic acid blends while on the contrary they have higher beneficial bacteria such as Lactobacilli in the ileum compared with those fed diets containing antibiotic growth promoters (Khan 2016). Higher Lactobacilli count may be due to less susceptibility to $\mathrm{pH}$ changes while coliforms are more sensitive to $\mathrm{pH}$ reductions than Lactobacilli in the GIT (Kim et al., 2009). Organic acids has property of lowering the $\mathrm{pH}$ of the gastrointestinal tract of birds thus may also prevent bacterial transfer from the diet or environment (Kil et al., 2011).

\section{Effect on gastrointestinal tract (GIT)}

In poultry industry it is a well established fact that success goes through gastrointestinal tract of poultry. Many researchers have documented positive effects of organic acid supplementation in terms of the villus height, width and area of small intestine (Rodríguez Lecompte et al., 2012). Pelicano et al., (2005) stated higher villus height in the ileum with the diet based on organic acid salts in comparison to the diet fed without mannan oligosaccharide (MOS) plus organic acids. Several other reports indicate that broilers fed diets containing formic acid had the longest villi compared with control i.e. $1088 \mu \mathrm{m}$. Short-chain fatty acids (SCFA) have been demonstrated to stimulate the proliferation of normal crypt cells, enhancing healthy tissue turnover and maintenance Leeson et al., (2005) and Panda et al., (2009) reported that butyrate, irrespective of concentrations $(0.2 \%$, $0.4 \%$ or $0.6 \%$ ) in the broiler's diet had improved the villus length and crypt depth in the duodenum. Adil et al., 2010 in another study concluded that the highest duodenal, jejuna and ileal villus heights were recorded in the birds fed diets supplemented with 3\% butyric acid, $3 \%$ fumaric acid and $2 \%$ fumaric 
acid, respectively. These pathogen substances cause disturbances in the normal micro-flora or in the intestinal epithelium, may alter the permeability of this natural barrier, thus facilitating the invasion of pathogens resulting in modification of the metabolism i.e. ability to digest and absorb nutrients which leads to chronic inflammatory processes in intestinal mucosa (Khan, 2013).

\section{Effect on nutrient digestibility}

To achieve more returns in terms of lower feed conversion ratios one of the most logical approach seems to increase the nutrient digestibility. In a study by Ao et al., 2009 concluded that $2 \%$ citric acid in the broiler diet increased the retention of DM, CP and neutral detergent fibre. Similarly, Ghazala et al., (2011) reported that dietary $0.5 \%$ of either fumaric or formic acid and $0.75 \%$ of acetic or $2 \%$ citric acid improved crude protein (CP), ether extract (EE), crude fibre (CF) and nitrogen-free extract (NFE) of broiler diets. More-over, Hernandez et al., (2006) and Garcia et al., (2007) reported that supplementation of formic acid $(0.5 \%)$ in broiler finisher diet improved apparent ileal digestibility of DMand CP as compared with control . According to Jongbloed et al., (2000) reduced $\mathrm{pH}$ in the upper part of the GIT may increase nutrient digestibility in diets.

\section{Effect on immune system}

Several studies on organic acids have demonstrated stimulatory effect on natural immunity in poultry. Lohakare et al., (2005) in his study measured titers of infectious bursal disease (IBD) post vaccination showed significantly higher IBD titres in Vitamin C $(0.2 \%)$ supplemental group. There was significant in-crease in CD4 and TCR-II cells in the $0.1 \%$ Vitamin $\mathrm{C}$ group as compared with control and these cells participate in the immune response to the exogenous antigen, stimulating the synthesis of Interleukin-2, which activates $\mathrm{CD} 8$, natural killer (NK) cells and B cells. In a study by Ghazala et al., (2011) birds fed an organic acid supplemented diet had heavier immune organs (bursa of Fabricius and the thymus) and higher level of globulin in their serum as well. Houshmand et al., (2012) found that dietary addition of organic acids resulted in significant increases in antibody titres against Newcastle disease in broilers.

\section{References}

Adil, R., Imtiyaz, Q.M. and Khan, T.M. 2010. Effect of feeding organic acids on intestinal health of broilers. Poultry Science. 31:54-58

Alp, M., Midilli, M., Kocaba_Gli, N., Y1lmaz, H., Turan, N. and Gargil1, A. 2012. The effects of dietary oregano essential oil on live performance, carcass yield, serum immunoglobulin $\mathrm{G}$ level, and oocyst count in broilers. Journal of Applied Poultry Research. 21: 630e6.

Amorati, R., Foti, M.C. and Valgimigli, L. 2013. Antioxidant activity of essential oils. Journal of Agriculture Food Chemistry. 46: 10835-10847.

Ao, T., Cantor, A.H., Pescatore, A.J., Ford, M.J., Pierce, J.L. and Dawson, K.A. 2009. Effect of enzyme supplementation and acidification of diets on nutrient digestibility and growth performance of broiler chicks. Poultry Science. 88:111-117.

Awaad, M.H.H., Abdel -Alim, G.A., Sayed, K.S., Ahmed, K.A., Nada, A.A., Metwalii, A.S.Z. and Alkhala, A.N. 2010. Immunostimulant effects of essential oils of peppermint and eucalyptus in chickens. Pakistan Veterinary Journal. 2: 61-66.

Bakkalil, F. 2008. Biological effects of essential oils - A review. Food and 
Chemical Toxicology, v.46, p.446-475.

Bang, K.H., Lee, D.W., Park, H.M. and Rhee, Y.H. 2000. Inhibition of fungal cell wall synthesizing enzymes by transcinnamaldehyde. Bioscience, Biotechnology, and Biochemistry. 64:1061-63.

Barbour, E.K., Bragg, R.R., Karrouf, G., Iyer, A., Azhar, E. and Harakeh, S. 2015. Control of eight predominant Eimeria spp. involved in economic coccidiosis of broiler chicken by a chemically characterized essential oil. Journal of Applied Microbiology. 118:583e91.

Brenes, A. and Roura, E.2010. Essential oils in poultry nutrition: Main effects and modes of action. Animal. Feed Science Technology. 158: 1-14.

Conner, D.E. 1993. Naturally occurring compounds. In: Antimicrobials in Foods, Davidson, P. M., and A. L. Branen, eds. Dekker, New York. pp. 441-468.

Cowan, M. 1999. Plant products as antimicrobial agents. Clinical Microbiology. Rev. 12: 564-582.

Dorman, H.J.D. and Deans, S.G. 2000. Antimicrobial agents from plants: antibacterial activity of plant volatile oils. Journal of Applied Microbiology. 88: 308-16.

Elson, C. E., Underbakke, G. L., Hanson, P., Shrago, E., Wainberg, R.H.and Qureshi, A.A.1989. Impact of lemongrass oil, an essential oil, on serum cholesterol. Lipids. 24: 677-679.

Farag, R.S., Daw, Z.Y., Hewed, F.M.and ElBaroty, G.S.A. 1989. Antimicrobial activity of some Egyptian spice essential oils. Journal ofFood Protection. 52: 665-667.

Faramarzi, S., Bozorgmehrifard, M.H., Khaki A., Moomivand, H., Ezati, M.S., Rasoulinezhad, S., Bahnamiri, A.J. and Dizaji, B. 2013. Study on the effect of Thymus vulgaris essential oil on humoral immunity and performance of broiler chickens after La Sota vaccination. Annals of Biological Research. 6: 290-294.

Garcia, V., Catala-Gregori, P. and Hernandez, F. 2007.Effect of formic acid and plant extracts on growth, nutrient digestibility, intestine mucosa morphology, and meat yield of broilers. Journal of Applied Poultry Research. 16(4):555-562.

Ghazala, A.A., Atta, A.M., Elkloub, K., Mustafa, M.E.L. andShata, R.F.H. 2011 Effect of dietary supplementation of organic acids on performance, nutrients digestibility and health of broiler chicks. International Journal of Poultry Science. 10(3):176-184

Gopi,M., Karthik, K., Vasanthacha, H., Tamilmahan, P., Kesavan,M., Dashprakash, M. Balaraju, B.L. and Purushothaman, M.R.2014.Essential Oils as a Feed Additive in Poultry Nutrition. Advance in Animal Veterinary. Science. 2 (1): $1-7$.

Habibi, R., Sadeghi, G. andKarimi, A. 2014. Effect of different concentrations of ginger root powder and its essential oil on growth performance, serum metabolites and antioxidant status in broiler chicks under heat stress. British Poultry Science.55:228e37.

HernáNdez, F., Garciá, V.,Madrid, J., Orengo, J. and Catalá, P. 2006. Effect of formic acid on performance, digestibility, intestinal histomorphology and plasma metabolite levels of broiler chickens. British Poultry Science. 47:50-56.

Houshmand, M., Azhar, K., Zulkifli, I., Bejo, M.H. andKamyab, A. 2012. Effects of nonantibiotic feed additives on performance, immunity and intestinal morphology of broilers fed different levels of protein. South African Journal of Animal Science. 42:22-32.

Jamroz, D., Wiliczkiewicz, A., Wertelecki, 
T., Orda, J. and Sukorupinska, J. 2005. Use of active substances of plant organic chicken diets based on maize and locally grown cereals. British Poultry Science. 46: 485-93.

Jang, I.S., Ko, Y.H., Kang, S.Y. and Lee, C.Y. 2007. Effect of a commercial essential oil on growth performance, digestive enzyme activity and intestinal microflora population in broiler chickens. Animal Feed Science and Technology. 134:304-315.

Jerzsele, A., Szeker, K., Csizinszky, R., Gere, E., Jakab, C. and Mallo, J. 2012. Efficacy of protected sodium butyrate, a protected blend of essential oils, their combination, and Bacillus amyloliquefaciens spore suspension against artificially induced necrotic enteritis in broilers. Poultry Science. 91:837e 43

Jongbloed, A.W., Mroz, Z., Van der WeijJongbloed, R. and Kemme, P.A. 2000. The effects of microbial phytase, organic acids and their interaction in diets for growing pigs. Livestock Production Science. 67:113-122

Karadas F, Pirgozliev V, Rose S, Dimitrov D, Oduguwa O, Bravo D. 2014. Dietary essential oils improve the hepatic antioxidative status of broiler chickens. British Poultry Science. 55:329e34.

Khan, S.H. 2013. Probiotic microorganismsidentification, metabolic and physiological impact on poultry. World's Poultry Science Journal. 69:601-612.

Khan, S.H. and Iqbal, J. 2016. Recent advances in the role of organic acids in poultry nutrition. Journal of Applied Animal Research. 44: (1)359-369.

Kil, D.Y., Kwon, W.B. and Kim, B.G. 2011. Dietary acidifiers in weanling pig diets: a review. Revista Colombiana de Ciencias Pecuarias. 24:231-247.

Kim, D.W., Kim, J.H., Kim, S.K., Kang,
G.H., Kang, H.K., Lee, S.J. and Kim, S.H. 2009. A study on the efficacy of dietary supplementation of organic acid mixture in broiler chicks. Korean Journal of Animal Science Technology. 51: 207-216.

Koyuncu, S., Andersson, M.G., Lofstrom, C., Skandamis, P.N., Gounadaki, A., Zentek, J. and Häggblom, P. 2013. Organic acids for control of Salmonella in different feed materials. $B M C$ Veterinary Research. 1746-6148/9/81.; 9:81.

Kreydiyyeh, S.I., Usta, J. and Copti, R. 2000. Effect of cinnamon, clove and some of their constituents on the $\mathrm{Na}+-\mathrm{K}+-$ ATPase activity and alanine absorption in the rat jejunum. Food and Chemical Toxicology. 38: 755-62.

Kum, S., Eren, U., Onol, A. and Sandikci, M. 2010 Effects of dietary organic acid supplementation on the intestinal mucosa in broilers. Revue de Médecine Vétérinaire.; 161:463-468.

Lee, H.S. and Ahn, Y.J. 1998. Growinginhibiting effects of Cinnamomum cassia bark derived materials on human intestinal bacteria. Journal of Agriculture and Food Chemistry. 46: 812.

Lee, K-W., Everts, H., Kappert, H., Frehner, M., Losa, R. and Beynen, A. 2003. Effects of dietary essential oil components on growth performance, digestive enzymes and lipid metabolism in female broiler chickens. British Poultry Science. 44:450e7.

Leeson, S., Namkung, H., Antongiovanni, M. and Lee, E.H. 2005. Effect of butyric acid on the performance and carcass yield of broiler chickens. Poultry Science.84:1418-1422.

Lohakare, J.D., Ryu, M.H., Hahn, T-W., Lee, J.K. and Chae, B.J. 2005. Effects of supplemental ascorbic acid on the performance and immunity of 
commercial broilers. Journal of Applied Poultry Research. 14:10-19.

Mellor, S. 2000. Nutraceuticals - alternatives to antibiotics. World Poultry. 16 (2): 30-33.

Nazzaro F, Fratianni F, De Martino L, Coppola R, De Feo V. 2013. Effect of essential oils on pathogenic bacteria. Pharmaceuticals Basel. 25; 6(12):145174.

Panda, A.K., Rao, S.V.R., Raju, M.V.L.N. and Sunder, G.S. 2009. Effect of butyric acid on performance, gastrointestinal tract health and carcass characteristics in broiler chickens. Asian-Australasian Journal of Animal Science. 22:10261031

Paul, S.K., Halder, G., Mondal, M.K. and Samanta, G. 2007. Effect of organic acid salt on the performance and gut health of broiler chicken. Journal of Poultry Science. 44:389-395.

Placha, I., Takacova, J., Ryzner, M., Cobanova, K., Laukova, A. and Strompfova, V. 2014. Effect of thyme essential oil and selenium on intestine integrity and antioxidant status of broilers. British Poultry Science. 55:105e14.

Platel, K. and Srinivasan, K. 2000. Influence of dietary spices and their active principles on pancreatic digestive enzymes in albino rats. Nahrung. 44: $42-46$.

Rodríguez -Lecompte, J.C., Yitbarek, A., Brady, J., Sharif, S., Cavanagh, M.D., Crow, G., Guenter, W., House, J.D. and Camelo-Jaimes, G. 2012. The effect of microbial nutrient interaction on the immune system of young chicks after early probiotic and organic acid administration. Journal of Animal Science. 90: 2246-2254.

Saleh,N., Allam,T., El-latif, A. A. and Ghazy, E.2014. The Effects of Dietary Supplementation of Different Levels of Thyme (Thymus vulgaris) and Ginger (Zingiber officinale) Essential Oils on Performance, Hematological, Biochemical and Immunological Parameters of Broiler .Global Veterinaria. 12 (6): 736-744.

Sambaiah, K. and Srinivasan, K. 1991. Secretion and composition of bile in rats fed diets containing spices. Journal of Food Science \&Technology. 28: 35-38.

Shapiro, S. and Guggenheim, B.1995. The action of thymol on oral bacteria. Microbiology and Immunology. 10: 241-246.

Stiles, J.C., Sparks, W. and Ronzio, R.A. 1995. The inhibition of Candida albicans by oregano. Journal of Applied Nutrition. 47: 96-102.

Wenk, C. 2000. Recent advances in animal feed additives such as metabolic modifiers, antimicrobial agents, probiotics, enzymes and highly available minerals. Review. AsianAustralian Journal of Animal Science. 13: 86-95

Zeng, Z., Zhang, S., Wang, H. and Paio, X. 2015. Essential oil and aromatic plants as feed additives in non-ruminant nutrition: a review. Journal of Animal Science and Biotechnology.6:7-15.

\section{How to cite this article:}

Raina Doneria, Meenu Dubey, M.K. Gendley, R.C. Ramteke and Rupal Pathak. 2020. Essential oils and Organic Acids: Feed Additive in Broiler Chickens. Int.J.Curr.Microbiol.App.Sci. 9(06): 3586-3593. doi: https://doi.org/10.20546/ijcmas.2020.906.422 